\title{
Building bridges not walls: the past, present, and future of international collaboration and research in northwest Mexico
}

\section{Construyendo puentes en vez de muros: pasado, presente y futuro de colaboraciones internacionales e investigación en el noroeste de México}

For the second time the annual meeting of the Western Society of Naturalists (WSN) was held in Mexico, acknowledging the importance of maintaining and augmenting collaboration and communication across regions within the California Current ecosystems regardless of political borders. To commemorate the society's "centenario" or 100th meeting and to mark the commitment among members to maintain international collaborations, this Ciencias Marinas issue includes 10 manuscripts from research presented at the WSN meeting held in Ensenada, Mexico, from October 31 to November 3, 2019, where 235 talks and 121 posters were presented. In concordance with the special topics addressed throughout the conference, here we present a brief summary of the history of marine research in northwest Mexico and emphasize how these efforts have changed through time. We also discuss the importance of continuing international collaborations to improve our understanding and management of ecosystems within the Northeast Pacific, as well as the role WSN plays in fostering transboundary international research.

Although indigenous communities of the region have held vast knowledge of marine species, coastal currents, and coastal geography, historically academia has failed to include and preserve indigenous knowledge. As such, the most commonly accessible early data from the Northeast Pacific on these marine subjects comes from Spanish conquistadores in the 1700s (Del Barco 1988) and American whalers in the early 1800s (Scammon 1874), who traveled extensively along the coast and published their observations. These early publications in the late nineteenth and early twentieth centuries were mainly descriptive, focusing on taxonomy (Verrill 1869) and species distribution (Jordan and Evermann 1896). In particular, these early observations highlighted the differences in fauna between the Gulf of California and the western Pacific coast side of the peninsula, and the similarities in fauna between Baja California and California (Deichmann 1941).

Despite the two World Wars resulting in a general hiatus in research, some "amateur" naturalists generated some quintessential information during this time and shortly after there was a swell in academic research (McClatchie 2014). For example, the book "Sea of Cortez: A Leisurely Journal of Travel and Research" by Steinbeck and Ricketts (1941) still represents the best available "pristine" baseline to compare to current conditions along the region (Sagarin et al. 2008). Scientific research programs such as the Allan Hancock Foundation Pacific Expeditions and the California Cooperative Oceanic Fisheries Investigations were created and improved the knowledge exponentially of the marine fauna and flora of California, northwest Mexico, and the entire Eastern Tropical
Por segunda vez la Western Society of Naturalists (WSN) llevó a cabo su reunión anual en México, acto con el que reconoce la importancia de mantener y aumentar la colaboración y la comunicación entre las diferentes regiones de la corriente de California, independientemente de las fronteras políticas. Para conmemorar el "centenario" o reunión número 100 de la sociedad y marcar el compromiso de los miembros de mantener las colaboraciones internacionales, este número de Ciencias Marinas incluye 10 manuscritos de investigaciones presentadas en la reunión de la WSN realizada en Ensenada, México, del 31 de octubre al 3 de noviembre de 2019, donde se presentaron 235 charlas y 121 pósters. En concordancia con los temas especiales abordados en el congreso (WSN 2019), aquí presentamos un resumen breve de la historia de la investigación marina en el noroeste de México y enfatizamos cómo estos esfuerzos han cambiado a través del tiempo. También discutimos la importancia de continuar las colaboraciones internacionales para mejorar nuestra comprensión y manejo de los ecosistemas marinos del Pacífico Nororiental, así como el papel que juega la WSN en fomentar la investigación internacional transfronteriza.

Aunque las comunidades indígenas de la región han poseído un conocimiento vasto de especies marinas, corrientes costeras y geografía costera, en el pasado la academia no ha incluido o preservado el conocimiento indígena. Debido a esto, la información temprana sobre el noroeste de México normalmente viene de los conquistadores españoles en el siglo XVIII (Del Barco 1988) y balleneros estadounidenses a principios del siglo XIX (Scammon 1874), quienes publicaron sus observaciones de sus extensos viajes a lo largo de la costa. Estas publicaciones de finales del siglo XIX y principios del siglo XX son principalmente descriptivas, centradas en la taxonomía (Verrill 1869) y la distribución de especies (Jordan y Evermann 1898). Particularmente, estas observaciones tempranas destacaron las diferencias entre la fauna del golfo de California y la del lado oeste de la península, y las similitudes entre la fauna de Baja California y California (Deichmann 1941).

A pesar de que las dos guerras mundiales resultaron en una pausa general en la investigación científica, algunos naturalistas "amateur" generaron información esencial durante este periodo y poco después hubo un incremento en la investigación marina (McClatchie 2014). Por ejemplo, el libro "Sea of Cortez: A Leisurely Journal of Travel and Research" por Steinbeck y Ricketts (1941) todavía representa el mejor registro de una línea base o "prístina" de ecosistemas no perturbados para comparar con condiciones actuales a lo largo de la región (Sagarin et al. 2008). Por otra parte, se crearon programas como las Allan Hancock Foundation Pacific 
Pacific (Clark 1938, McClatchie 2014). Moreover, there was a surge in research during the 1950s and 1960s, and several US institutions, such as Scripps Institution of Oceanography, the American Museum of Natural History, Stanford University, the University of Southern California, San Diego Natural History Museum, and the University of California in Los Angeles, conducted research in northwest Mexico on varied subjects such as oceanography, ichthyology, and paleontology (Durham and Barnard 1952, Hubbs 1960, Roden 1958).

During this same period in Mexico, only a handful of universities offered undergraduate programs in biology, such as Universidad Nacional Autónoma de México (UNAM), Instituto Politécnico Nacional, and Universidad Autónoma de Nuevo León, and so the first (taxonomic) papers written by Mexican researchers on the marine fauna of the Pacific appeared (Rioja 1948, Caso 1953). Systematic research on marine species of northwest Mexico started in the 1960s, likely fostered by the interest of the federal government to increase commercial fishing (Castro-Aguirre 1965). In 1960, the Universidad Autónoma de Baja California (UABC) established the Escuela Nacional de Ciencias Marinas, with a Bachelor of Science degree in Oceanology, the first in Mexico and Latin America, and initiated oceanographic research in Mexico. Subsequently, most university marine science programs throughout the country (i.e., marine biology, fisheries biology, hydrobiology, oceanology) started in the 1970s (Martin del Campo 1987).

The Consejo Nacional de Ciencia y Tecnología (CONACYT, Mexico) was founded in 1970 with the goal of strengthening the development of science and technology in Mexico. The CONACYT budget reached an all-time high in the 1980s, and the number of marine research projects increased dramatically, particularly in the northwest. In 1981 Mexico bought its first fully-equipped oceanographic ships ("El Puma" and "Justo Sierra", owned by UNAM and Petróleos Mexicanos; Hendrickx 2012). During this period, CONACYT's national and international graduate scholarship programs were established. Throughout the 1980s research conducted by Mexican scholars increased, but most published research was done by US scholars (Fig. 1), in part due to the lack of $\mathrm{PhD}$ programs in Mexico. However, through CONACYT's scholarship program, many students were able to obtain master's and doctoral degrees abroad (e.g., ecology, aquaculture, and fisheries), mainly in the USA, Japan, the UK, and Spain, leading to subsequent increases in Mexican research publications.

In the 1990s, many Mexican students who had studied marine sciences abroad began to return to Mexico and continue their research. By then, Mexican marine research institutions were also awarding master's and doctoral degrees, and funding was available for research from government sources, such as CONACYT, which increased the quality of research and the output. Coordination, collaboration, and exchanges with US researchers continued, but increasingly Mexican scholars worked independently. By the 2000s, the
Expeditions y la California Cooperative Oceanic Fisheries Investigations, que mejoraron exponencialmente el conocimiento de la fauna y flora marina de California, el noroeste de México y todo el Pacífico Tropical Oriental (Clark 1938, McClatchie 2014). Durante las décadas de 1950 y 1960, hubo un incremento en la investigación de varias instituciones estadounidenses, como Scripps Institution of Oceanography, the American Museum of Natural History, Stanford University, University of Southern California, San Diego Natural History Museum y University of California Los Angeles, las cuales condujeron investigaciones en varios tópicos como oceanografía, ictiología y paleontología en el noroeste de México (Durham y Barnard 1952, Hubbs 1960, Roden 1958).

Durante este mismo período, en México sólo unas cuantas universidades ofrecían programas de licenciatura en biología, tales como la Universidad Nacional Autónoma de México (UNAM), Instituto Politécnico Nacional y la Universidad Autónoma de Nuevo León, y aparecieron los primeros artículos (taxonómicos) escritos por autores mexicanos sobre la fauna marina del Pacífico (Rioja 1948, Caso 1953). La sistemática de las especies marinas del noroeste de México comenzó en la década de 1960, probablemente fomentada por el interés del gobierno federal de aumentar la producción de las pesquerías comerciales (Castro-Aguirre 1958). En 1960, la Universidad Autónoma de Baja California (UABC) estableció la Escuela Nacional de Ciencias Marinas, la cual ofrecía una licenciatura en Oceanología, la primera en México y Latinoamérica, e inició la investigación oceanográfica moderna en México. Subsecuentemente, en la década de 1970, aparecieron la mayoría de los programas universitarios de ciencias marinas a nivel nacional (i.e., biología marina, biología pesquera, hidrobiología, oceanología, etc.; Martin del Campo 1987).

El Consejo Nacional de Ciencia y Tecnología (CONACYT, México) fue fundado en 1970 con el objetivo de fortalecer el desarrollo científico y tecnológico en México. El presupuesto de CONACYT alcanzó su máximo en la década de 1980, y el número de proyectos de investigación marina se incrementó dramáticamente, particularmente en el noroeste del país. En 1981, México compró sus primeros buques oceanográficos completamente equipados ("El Puma" y "Justo Sierra", propiedad de la UNAM y Petróleos Mexicanos; Hendrickx 2012). También, durante este periodo, se establecieron los programas de becas de posgrado nacionales e internacionales de CONACYT. Durante la década de 1980, se incrementó la cantidad de investigaciones conducidas por científicos mexicanos, pero la mayoría de las investigaciones publicadas fueron llevadas a cabo por investigadores estadounidenses (Fig.1), parcialmente debido a la escasez de programas de doctorado en México. Sin embargo, debido al programa de becas CONACYT, muchos estudiantes tuvieron la oportunidad de obtener maestrías y doctorados en el extranjero (e.g., ecología, acuacultura y pesquerías), principalmente en EUA, Japón, Inglaterra y España, lo cual subsecuentemente incrementó las publicaciones por investigadores mexicanos. 


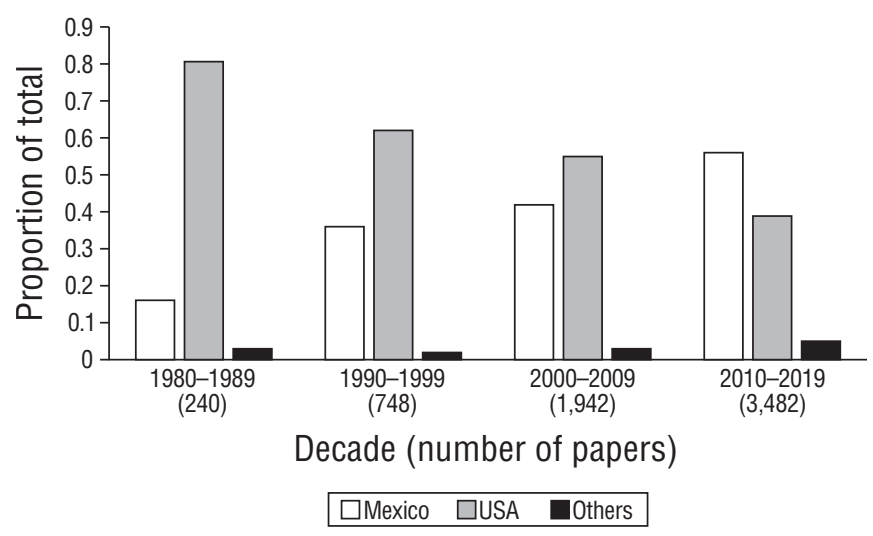

Figure 1. Percentage of marine science articles published from research done in Northwest Mexico by decade and country of the institution of the first author. The data were obtained by searching the Web of Science database using the key words "Gulf of California OR Pacific Coast Baja California”. Total number of papers found per decade are in parenthesis.

Figura 1. Porcentaje de los artículos de ciencias marinas publicados sobre investigaciones llevadas a cabo en el noroeste de México, clasificados por década y país de la institución del primer autorLos datos fueron obtenidos de la base de datos Web of Science con las palabras clave "Gulf of California OR Pacific Coast Baja California”. El número total de artículos encontrados por década se encuentra en paréntesis.

undergraduate students of the 1970s and 1980s were now independent researchers with over 10 years of experience. Globalization also played a role in diversifying and strengthening marine science in Mexico; many $\mathrm{PhD}$ graduates from Europe (mainly Spain) and South America arrived to Mexican institutions, providing further avenues for diverse collaborations. Additionally, non-governmental organizations, such as ProNatura Noroeste, Sociedad de Historia Natural Niparajá, Comunidad y Biodiversidad, and many others became key actors supporting marine research in northwest Mexico with grants from national and international foundations and governments.

Finally, in recent years, Mexican scholars accelerated their output to the point that the majority of marine research published in the last decade (2010-2019) in Northwest Mexico has been authored by Mexican nationals (Fig. 1), although researchers from US institutions still produced around $40 \%$. These trends and evident historically shared research interest among USA and Mexican scholars present great opportunities for continuing to foster and strengthen transboundary academic collaborations, a common theme during the 100th WSN meeting.

The synergistic nature of collaborating among scientists from different countries is an ideal to continue to strive for. Within this WSN special issue, the 10 articles published are a very small fraction of all the collaborative work presented and cited during the meeting but still highlight how research is enhanced by such diverse collaborations. The research by
En la década de 1990, muchos estudiantes mexicanos que estudiaron ciencias marinas en el extranjero empezaron a retornar a México para continuar sus investigaciones. Para entonces las instituciones mexicanas de investigación marina ya ofrecían maestrías y doctorados, y había financiamiento disponible por parte de agencias de gobierno, como CONACYT, lo cual incrementó la calidad y cantidad de las investigaciones llevadas a cabo. La coordinación, la colaboración y los intercambios con investigadores estadounidenses continuó, pero los investigadores mexicanos, cada vez más, trabajaban independientemente. Para la década de 2000, los estudiantes de licenciatura de las décadas de 1970 y 1980 eran ya investigadores independientes con más de 10 años de experiencia. La globalización también jugó un papel en la diversificación y el fortalecimiento de las ciencias marinas en México. Muchos investigadores extranjeros, con doctorado, de Europa (principalmente de España) y de América del Sur llegaron a instituciones mexicanas y proporcionaron nuevas y diversas vías de colaboración. También organizaciones no gubernamentales como ProNatura Noroeste, Sociedad de Historia Natural Niparajá, Comunidad y Biodiversidad, y muchas otras se convirtieron en actores clave para el apoyo a la investigación marina en el noroeste de México, con financiamiento de fundaciones y gobiernos, nacionales e internacionales.

Finalmente, en años recientes, los investigadores mexicanos aceleraron su producción a tal punto que la mayoría de la investigación marina publicada en la última década (20102019) en el noroeste de México ha sido escrita por mexicanos (Fig 1.), aunque los investigadores de instituciones estadounidenses aún producen alrededor del 40\%. Estas tendencias y los intereses de investigación que históricamente han sido similares y compartidos entre académicos estadounidenses y mexicanos, presentan grandes oportunidades para continuar fomentando y fortaleciendo colaboraciones académicas transnacionales, un tema común durante el centenario del congreso de la WSN.

La naturaleza sinérgica de las colaboraciones científicas entre personas de diferentes países es un ideal que merece seguir fomentadose. Dentro de esta edición especial de la WSN, los 10 artículos publicados son una pequeña fracción de todo el trabajo colaborativo presentado y citado durante la reunión; no obstante, resaltan cómo la calidad de la investigación puede ser mejorada por estas colaboraciones tan diversas. La investigación de Bauer et al. (este número) integró perspectivas de investigadores mexicanos y estadounidenses y una cooperativa pesquera local para brindar información para los esfuerzos de acuicultura, manejo y conservación de una pesquería de gran valor, pero amenazada. Otras colaboraciones binacionales incluyen la de Thonlan et al. (este número), quienes describieron la ictiofauna de islas remotas y poco estudiadas en las aguas del Pacífico frente a México, y la de Velasco-Lozano et al. (este número), quienes analizaron comunidades de peces mesofóticas en el sur del golfo de California e identificaron refugios profundos para algunas 
Bauer et al. (this issue) integrated wide perspectives from Mexican and USA researchers and a local fishing cooperative to inform aquaculture, management, and conservation of a valuable, endangered fishery. Other binational collaborations include Tholan et al. (this issue), who described the ichthyofauna of remote and rarely studied islands in Pacific waters off Mexico, and Velasco-Lozano et al. (this issue), who analyzed mesophotic fish communities in the southern Gulf of California and identified the reservoir of species found at these previously unknown depths that are in need of protection.

Other papers within this issue are also of key regional relevance. Lowe and Galloway (this issue) identified a greater depth range of red sea urchins than had previously been reported, information relevant to the management and future research of this important marine resource that distributes from Mexico to Canada. Vendetti (this issue) described the larval development of the Kellet's whelk, a large gastropod that is part of an emerging fishery in California and Baja California. Leonardi et al. (this issue) analyzed the morphological variation of colloblasts (specialized cells for predation) from 20 species of ctenophores, contributing to a better understanding of the functional diversity of pelagic species. Vargas-Peralta et al. (this issue) reported the complete genome of the halibut, Paralichthys californicus, improving the knowledge of a species that is distributed and exploited across the temperate northeastern Pacific. Hansen et al. (this issue) highlighted the strong negative impact of introduced red mangroves on endemic Hawaiian fish populations, supporting the need for eradication of the invasive mangroves. Payan-Alcacio et al. (this issue) described the functional fish diversity in arid mangrove habitats of the Gulf of California, highlighting this important yet fragile ecosystem. Dolinar et al. (this issue) quantified the effects of mooring disturbance on rhodolith community ecophysiology, a research with broad implication to management of this important ecosystem both in Mexico and the Northeast Pacific (highlighted Cabello-Pasini and Riosmena-Rodriguez 2007).

Transcending political borders and promoting collaborative work among nations is an important goal in the management and conservation of shared marine resources. Canada, the USA, and Mexico share marine resources and a long history of social, economic, cultural, and ecological interactions. In our dynamic and stochastic world, and particularly in a region as the Northeast Pacific, transboundary research is not only an important goal but also meets a definite research and management need. A transboundary, interdisciplinary, and collaborative approach to research projects fosters greater breadth and efficacy when tackling complicated issues that do not stop at political borders. The WSN intends to continue to support such essential communication and collaboration among a diverse array of scientists regardless of race, gender, religion, sexual orientation, disability, socioeconomic background, language, ability, age, and political perspective in order to shed light on the common ground of elucidating ecology, evolution, natural history, and marine biology. especies, que nunca habían sido halladas a estas profundidades y necesitan protección.

Otros artículos dentro de esta edición son también de gran relevancia regional. Lowe y Galloway (este número) identificaron un nuevo máximo de profundidad para el erizo rojo, información que es relevante para el manejo y las investigaciones futuras de este importante recurso marino que se distribuye desde México hasta Canadá. Vendetti (este número) describieron el desarrollo larval del buccino de Kellet, un gasterópodo grande que es parte de una pesquería emergente en California y Baja California. Leonardi et al. (este número) analizaron la variación morfológica de los coloblastos (células especializadas para la depredación) de 20 especies de ctenóforos, lo cual contribuye a una mejor comprensión de la diversidad funcional de especies pelágicas. Vargas-Peralta et al. (este número) reportaron el genoma completo del lenguado californiano, Paralichthys californicus, lo cual mejora el conocimiento de una especie que se distribuye y explota a través del Pacífico Nororiental templado. Hansen et al. (este número) resaltaron el fuerte impacto negativo del mangle rojo, una especie introducida, en poblaciones endémicas de peces hawaianos, un trabajo que apoya la necesidad de erradicar estos mangles invasores. Payan-Alcacio et al. (este número) describieron la diversidad funcional de peces en manglares de zonas áridas en el golfo de California, algo que resalta la importancia y la fragilidad de estos ecosistemas. Dolinar et al. (este número) cuantificaron los efectos de la perturbación causada por anclajes en la ecofisiología de las comunidades de rodolitos, resultados con implicaciones para el manejo de este importante ecosistema tanto en México como en el Pacífico Nororiental (destacado en Cabello-Pasini y Riosmena-Rodriguez 2007).

Una meta importante en el manejo y la conservación de recursos marinos compartidos es el de trascender fronteras políticas y promover trabajos colaborativos entre naciones. Canadá, EUA y México comparten recursos marinos y una larga historia de interacciones sociales, económicas, culturales y ecológicas. En este mundo dinámico y estocástico, y particularmente en una región como el Pacífico Nororiental, la investigación transfronteriza no es tan sólo una meta importante, sino que satisface una necesidad concreta de manejo y de investigación. Un enfoque transfronterizo, interdisciplinario y colaborativo de los proyectos de investigación fomenta una mayor eficacia y amplitud de respuesta al enfrentar problemas complejos que no obedecen fronteras políticas. La WSN pretende continuar apoyando la comunicación y la colaboración entre científicos de diversas razas, géneros, religiones, orientaciones sexuales, capacidades diferentes, historiales socioeconómicos, lenguas, habilidades, edades y perspectivas políticas con el fin de destacar nuestro interés común de elucidar temas de ecología, evolución, historia natural y biología marina.

Agradecemos todo el apoyo recibido para llevar a cabo la reunión de la WSN en Ensenada en 2019 y para la realización de esta edición Ciencias Marinas. Estamos en deuda 
We gratefully acknowledge the wide range of support received that led to both the 2019 WSN Ensenada meeting and this special issue of Ciencias Marinas. We are indebted to the support from the WSN, UABC students, faculty and administrators, Hotel Coral y Marina, invited speakers, and meeting attendees. This special issue of Ciencias Marinas was improved by the work of special issue section editors, reviewers, and authors. We would like to specially thank Lucía M Rodríguez and Sarah J Teck for their valuable comments. All of these contributions to the meeting and journal are an example of collaborative investigation and work. con la dirección ejecutiva de la WSN por su apoyo, al igual que con los estudiantes, profesores y administradores de la UABC, el Hotel Coral y Marina, los ponentes invitados y los asistentes a la reunión. La calidad de este número especial de Ciencias Marinas es gracias al trabajo de los editores, revisores y autores. Nos gustaría agradecer especialmente a Lucía M Rodríguez y Sarah J Teck por sus valiosos comentarios. Todas estas contribuciones a la reunión y a la revista son un ejemplo de investigación y trabajo colaborativo.

Traducido al español por Lucía M Rodríguez.

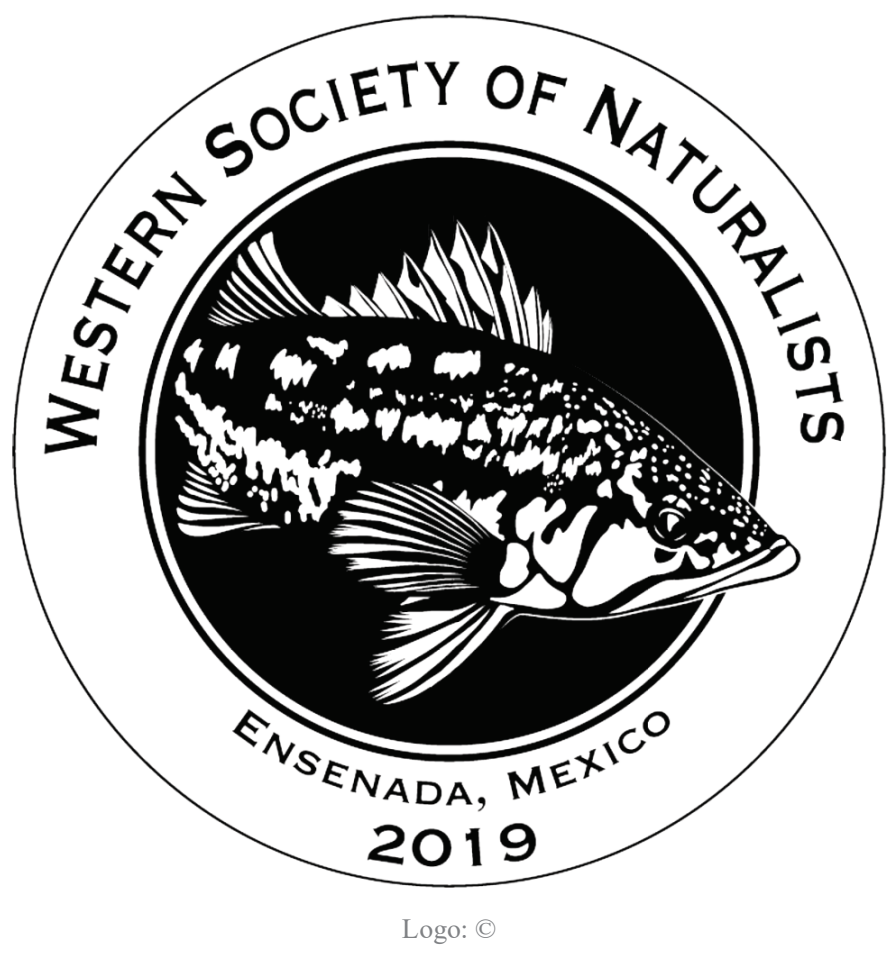

Julio Lorda, Rodrigo Beas-Luna

Organizers/Organizadores

Luis Malpica-Cruz, Héctor Reyes-Bonilla

WSN members/Miembros WSN

Brian N Tissot

WSN President in 2019

Diana Steller

Guest editor/Editora invitada 


\section{REFERENCES}

Caso ME. 1953. Estado actual de los conocimientos acerca de la fauna de los equinodermos de México. Memoria Del Congreso Científico Mexicano, Vol. 11. Mexico City: Universidad Nacional Autónoma de México. p. 209-222.

Castro-Aguirre JL. 1965. Peces sierra, rayas, mantas y especies afines de México. Anal Inst Nac Invest Biol Pesq. 1:169-256.

Cabello-Pasini A, Riosmena-Rodrigues R (editors). 2007. Ciencias Marinas: II International Workshop on Rohodoliths. Cienc Mar. 33(4):335-501.

Clark HL. 1938. The Hancock Pacific Expeditions. Sci Mon. 47:511-518.

Deichmann E. 1941. The Holothuroidea collected by the Velero III during the years 1932 to 1938. Part I, Dendrochirota. Allan Hancock Pacific Exped. 8:61-194.

Del Barco M. 1988. Historia Natural y Crónica de la Antigua California: adiciones y correcciones a la Noticia de Miguel Venegas. 2nd ed. Mexico City: Universidad Nacional Autónoma de México, Instituto de Investigaciones Históricas. 482 p.

Durham JW, Barnard BL.1952. Stony corals of the eastern Pacific collected by the Velero III and Velero IV. Allan Hancock Pacific Exped. 16:1-110.

Hendrickx ME. 2012. Operaciones oceanográficas en aguas profundas: los retos del pasado, del presente y del proyecto TALUD en el Pacífico mexicano (1989-2009). In: Zamorano P, Hendrickx ME, Cas M (eds.), Biodiversidad y Comunidades del Talud Continental del Pacífico Mexicano. Mexico City: Instituto Nacional de Ecología. p. 23-104.

Hubbs CL. 1960. The Marine Vertebrates of the Outer Coast. Syst Biol. 9(3-4):134-147.

https://doi.org/10.2307/2411962
Jordan DS, Evermann BW. 1896. The fishes of North and Middle America: a descriptive catalogue of the species of fish-like vertebrates found in the waters of North America, north of the Isthmus of Panama. Washington (DC): US Government Printing Office. $1240 \mathrm{p}$.

Martin del Campo D. 1987. Los Mares de México: Crónicas de la Tercera Frontera. Mexico City: Universidad Autónoma Metropolitana. $237 \mathrm{p}$.

McClatchie S. 2014. Introduction to the Fisheries and the Surveys. In: McClatchie S (ed.), Regional Fisheries Oceanography of the California Current System. Dordrecht (Netherlands): The CalCOFI Program. Springer. p. 1-11.

Rioja E. 1948. Estudios Anelidologicos. XVII. Contribución al conocimiento de los anélidos poliquetos de Baja California y Mar de Cortés. Anal Inst Biol Univ Nac Autónoma México. 18:197-224.

Roden G. 1958. Oceanographic and meteorological aspects of the Gulf of California. Pacific Sci. 12:21-45.

Sagarin RD, Gilly WF, Baxter CH, Burnett N, Christensen J. 2008. Remembering the Gulf: changes to the marine communities of the Sea of Cortez since the Steinbeck and Ricketts expedition of 1940. Front Ecol Environ. 6:372-379. https://doi.org/10.1890/070067

Scammon CM. 1874. The Marine Mammals of the North-western Coast of North America, Described and Illustrated; Together with an Account of the American Whale-fishery. San Francisco (CA): John H. Carmany and Co. 319 p.

Steinbeck J, Rickets E. 1941. Sea of Cortez: A Leisurely Journal of Travel and Research. New York (NY): The Viking Press. 288 p.

Verrill AE. 1869. Notes on Radiata in the Museum of Yale College, Number 6: Review of the corals and polyps of the West Coast of America. Trans Connect Acad Arts Sci. 1:418-518. https://doi.org/10.5962/bhl.title.13387 